\title{
Alanine Aminotransferase 2
}

National Cancer Institute

\section{Source}

National Cancer Institute. Alanine Aminotransferase 2. NCI Thesaurus. Code C38509.

Alanine aminotransferase 2 (523 aa, $58 \mathrm{kDa}$ ) is encoded by the human GPT 2 gene. This protein is involved in both pyruvate biosynthesis and amino acid metabolism. 